\title{
The effectiveness of the mechanical treatment of municipal waste using the example of a selected installation
}

\author{
Marta Wiśniewska ${ }^{1, *}$, Krystyna Lelicińska-Serafn ${ }^{2}$ \\ ${ }^{1}$ Warsaw University of Technology, Faculty of Building Services, Hydro and Environmental \\ Engineering, Ground Surface Protection Team, ul. Nowowiejska 20, 00-653 Warsaw, Poland, \\ ${ }^{2}$ Warsaw University of Technology, Faculty of Building Services, Hydro and Environmental \\ Engineering, Waste Management Team, ul. Nowowiejska 20, 00-653 Warsaw, Poland
}

\begin{abstract}
The mechanical treatment of waste using specialized equipment allows the separation of significant amounts of secondary raw materials. To a large extent, the effectiveness of such a process depends on the quality of the input - one efficiency value is achieved during the segregation of mixed municipal waste, and the other one - during preprocessing of waste from separate collection. The work analysed the data on mechanical processing in a mechanical-biological treatment plant for municipal waste. The mechanical part of the installation is equipped with optical-electronic and electromagnetice separators, as well as manual sorting cabins. Results were obtained to compare the efficiency of the separation of secondary raw materials and energy fractions for further use, as well as the amount of undersieve fraction requiring biological stabilization and ballast waste, which are directed to landfilling.
\end{abstract}

\section{Introduction}

The functioning of the urban technical infrastructure is inherently related to waste management and installations for its processing. The increase in awareness of the value of waste caused intensive development of technologies serving their preparation for recycling and other recovery methods (e.g. energy recovery) [1,2]. These issues are the part of sustainable development of the city, which influences environmental protection in urban structures. The implementation of sustainable development is inseparably connected with the quality of the environment [3]. The sustainable development of the city should minimize its negative impact on the environment with special regard to waste management.

The efficiency of the separation of individual fractions from municipal waste on the one hand depends on the devices in which the treatment (sorting) plant is equipped, but on the other hand - on the characteristics of the waste subjected to the process, which in the case of municipal waste is determined largely by the type and quality of its selective collection in urban structures [4].

\footnotetext{
* Corresponding author: marta.wisniewska.89@wp.pl
} 
Due to the requirements of the circular economy, municipal waste treatment plants operating in Polish cities in the near future should be modernized in order to ensure higher efficiency in the mechanical part of the process, so that as much waste as possible can be used. The expected levels in this respect will force higher sorting effectiveness through the application of advanced mechanical processes and state-of-the-art equipment [5]. Today's waste regulation in the EU comprises stringent material recovery targets and calls for comprehensive programs in order to achieve them. Technology developed for the sorting of commingled recyclables from separate collection is also being successfully used to upgrade residual waste (mixed waste) processing plants [6]. Polish cities should adapt to these requirements.

One of the mechanical-biological treatment plants for municipal waste was analysed. The balance of waste delivered and subjected to mechanical processing (both from selective collection and collected as mixed stream) and the balance of waste generated as a result of this process are presented. The opportunities and trends in the use of modern devices (equipment) in this type of installations have also been shown.

\section{Sustainable development and waste management in a city - Waste Management Plant in Poświętne}

The Waste Management Plant (Regional Municipal Waste Treatment Installation for the western region (Ciechanów-Płock) in the Mazowieckie voivodeship), which is located in Poświętne near Płońsk, is equipped with a modern installation of mechanical-biological treatment of municipal waste. Until the end of April 2016, the plant was operated based on the administrative decision issued by the local authorities of Płońsk. Then, both mixed waste and selectively collected waste (from the western region - Płock, Płońsk, Ciechanów and other towns and communities) were treated together - contrary to the legal provisions required in waste management (Act of 14 December 2012 on Waste, consolidated text Journal of Laws of 2018, item 992) [7]). Since the beginning of May 2016, the installation has been operated based on an integrated permit (in accordance with the IPPC directive requirements of European Union law [8]). Since this moment, municipal waste from separate collection and mixed waste have been treated separately. The effects of these changes play an important role in relation to sustainable development and environmental protection. They are very well reflected by the waste balance [9].

\subsection{Mechanical processing - technical infrastructure}

The mechanical part in the analysed plant can function in two variants. The first variant takes into account the treatment of mixed municipal waste, the second one includes the mechanical treatment of waste collected selectively.

Mechanical treatment takes place using a technological line located in the sorting hall. The following main unit operations and devices in which these operations are carried out are used: weighing (registration and control - car weights), storage areas (bunkers), unloading (e.g. bag breaking devices), transport (conveyors - mainly belts), pre-sorting (sorting cabins with separate sorting conveyors), separation (ferrous metal separators electromagnetic ones, optical-pneumatic separators), and screening (three-fraction drum screen) - for separation into three fractions (size: $0 \div 80 \mathrm{~mm}, 80 \div 300 \mathrm{~mm}$ and over 300 $\mathrm{mm})$.

As a result of the technology the undersieve fraction $(0 \div 80 \mathrm{~mm})$, which mostly consists of biodegradable waste [6], is directed (after the above-mentioned separation) to the biological part of the installation for further processing. Secondary raw materials (mainly 
from the medium fraction $-80 \div 300 \mathrm{~mm}$ and the oversize fraction - greater than $300 \mathrm{~mm}$ ) are transported to the raw material storage zone and then passed to recipients for material recycling. Contaminants removed from them are treated as a component intended for the production of refuse derived fuel (fuel from waste) and passed to recipients for energy recovery. A part of the remaining waste (ballast) requires final disposal in a landfill [10].

\subsection{The equipment - as effective and useful utilities for municipal systems}

The basic equipment of the sorting line in the Waste Management Plant in Poświętne includes a drum sieve, six manual sorting cabins, two electromagnetic (belt) separators and three optical-pneumatic separators. The equipment used in the above-mentioned processing line enables separation of the following fractions and elements: PET, PP, PE, PS, foil, multi-material packaging and fabrics, paper, metals (ferrous and non-ferrous), textile waste, fractions for the production of refuse derived fuel (a high-calorie fraction), large-size and construction and demolition waste, used electrical and electronic equipment and hazardous waste (especially those that are easy to recognize, i.e. medicines and batteries) [10].

In the case of optical-pneumatic separators, the composition of the input material is very important, the material should not contain light foil and other low-density factions, as well as extremely heavy elements. Efficiency is significantly increased by the proper preparation of waste, which should be spread evenly on a belt conveyor so that it does not overlap. This is achieved thanks to the conveyors with a suitably wide belt, moving at the right speed. Otherwise, the waste will not be recognised by the equipment. Waste that is directed to the optical separator cannot be black or very dark, because it makes identification difficult. The space under the scanner should be protected against excessive access of sunlight or light from lamps, as this may result in a significant reduction in the efficiency of separation $[10$, $11,12]$.

\section{Balance of waste quantity - an element of environmental protection and sustainable development of cities}

Tables 1 shows a balance of waste mass subjected to sorting (mechanical treatment) and waste generated as a result of this process in the analysed plant when mixed waste and waste collected separately were treated together in the mechanical part of the installation.

Table 1. Balance of the amount of municipal waste treated mechanically and waste registered as generated at the Waste Management Plant in Poświętne (as a result of this process) in the period from January to April 2016 - a personal study (using [13]).

\begin{tabular}{|c|c|c|c|c|}
\hline \multicolumn{2}{|c|}{ Mechanical treatment - input waste } & \multicolumn{2}{|c|}{ Waste after mechanical processing } & \multirow{2}{*}{$\begin{array}{l}\text { Percentage of } \\
\text { generated waste } \\
\text { to the sum of } \\
\text { input waste [\%] }\end{array}$} \\
\hline Type of waste & $\begin{array}{c}\text { Waste } \\
\text { mass }[\mathrm{Mg}]\end{array}$ & $\begin{array}{l}\text { Type of waste } \\
\text { (waste code) }\end{array}$ & $\begin{array}{c}\text { Waste } \\
\text { mass }[\mathrm{Mg}]\end{array}$ & \\
\hline \multirow[t]{4}{*}{$\begin{array}{c}\text { Unsorted municipal } \\
\text { waste (mixed waste) } \\
\left(\begin{array}{l}200301)\end{array}\right.\end{array}$} & \multirow[t]{4}{*}{18452.5} & $\begin{array}{c}\text { Packaging (paper and } \\
\text { cardboard, plastic, metal, } \\
\text { glass, multi-material) } \\
(150101,1500102,15 \\
0104,150107,150105)\end{array}$ & 1413.7 & 7.30 \\
\hline & & $\begin{array}{c}\text { Paper and cardboard } \\
(191201)\end{array}$ & 18.2 & 0.09 \\
\hline & & $\begin{array}{l}\text { Ferrous metals } \\
(191202)\end{array}$ & 53.7 & 0.28 \\
\hline & & $\begin{array}{c}\text { Wood } \\
(191207)\end{array}$ & 9.2 & 0.04 \\
\hline
\end{tabular}




\begin{tabular}{|c|c|c|c|c|}
\hline \multirow[t]{4}{*}{$\begin{array}{l}\text { Other waste (mainly } \\
\text { from separate } \\
\text { collection) }\end{array}$} & \multirow[t]{4}{*}{928.9} & $\begin{array}{c}\text { Other waste from } \\
\text { mechanical processing } \\
\text { (total fraction } 0-80 \mathrm{~mm}) \\
(191212)\end{array}$ & 10967.1 & 56.59 \\
\hline & & $\begin{array}{c}\text { Other waste from } \\
\text { mechanical processing } \\
\text { (ballast) } \\
(191212) \\
\end{array}$ & 3377.8 & 17.43 \\
\hline & & $\begin{array}{c}\text { Other waste from } \\
\text { mechanical processing } \\
\text { (large-size waste) } \\
(191212)\end{array}$ & 670.5 & 3.46 \\
\hline & & $\begin{array}{l}\text { Other waste from } \\
\text { mechanical processing } \\
\text { (input for refuse derived } \\
\text { fuel production) } \\
(191212)\end{array}$ & 1868.3 & 9.64 \\
\hline TOTAL & 19381.4 & TOTAL & 18378.5 & $94.83^{*}$ \\
\hline
\end{tabular}

* the loss results from the significant water content in municipal waste, also water in closed bottles (outflow of leachate after opening the bags)

Tables 2 presents the balance of the amount of municipal waste from selective collection directed to sorting and waste generated as a result of this process in the reviewed Plant.

Table 2. Balance of the amount of municipal waste from separate collection and treated mechanically and waste registered as generated at the Waste Management Plant in Poświętne (as a result of this process) from May to December 2016 - a personal study (using [13]).

\begin{tabular}{|c|c|c|c|c|}
\hline \multicolumn{2}{|c|}{ Mechanical treatment - input waste } & \multicolumn{2}{|c|}{ Waste after mechanical processing } & \multirow{2}{*}{$\begin{array}{l}\text { Percentage of } \\
\text { generated waste } \\
\text { to the sum of } \\
\text { input waste [\%] }\end{array}$} \\
\hline Type of waste & $\begin{array}{c}\text { Waste } \\
\text { mass }[\mathrm{Mg}]\end{array}$ & $\begin{array}{l}\text { Type of waste } \\
\text { (waste code) }\end{array}$ & $\begin{array}{c}\text { Waste } \\
\text { mass }[\mathrm{Mg}]\end{array}$ & \\
\hline \multirow{5}{*}{$\begin{array}{c}\text { Waste from separate } \\
\text { collection }\end{array}$} & \multirow{5}{*}{1644.5} & $\begin{array}{l}\text { Packaging (paper and } \\
\text { cardboard, plastic, metal, } \\
\text { multi-material, glass) } \\
\text { (ex } 150101 \text {, ex } 150102,02, \\
\text { ex } 150104 \text { ex } 150105, \\
\text { ex } 150107 \text { ) }\end{array}$ & 1159.2 & 70.48 \\
\hline & & $\begin{array}{l}\text { Paper and cardboard } \\
(191201)\end{array}$ & 13.7 & 0.83 \\
\hline & & 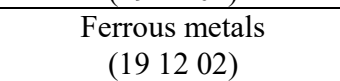 & 10.5 & 0.64 \\
\hline & & $\begin{array}{l}\text { Other waste from } \\
\text { mechanical waste } \\
\text { processing (high energy } \\
\text { fraction) } \\
(191212)\end{array}$ & 345.1 & 20.99 \\
\hline & & $\begin{array}{l}\text { Other waste from } \\
\text { mechanical waste } \\
\text { processing (ballast) } \\
(191212)\end{array}$ & 115.2 & 7.01 \\
\hline TOTAL & 1644.5 & TOTAL & 1643.7 & $99.95^{*}$ \\
\hline
\end{tabular}

* outflow of leachate after opening the bags 
Table 3 presents the balance of the amount of mixed municipal waste directed to sorting, and waste generated as a result of this process in the analysed Plant after the integrated permit was obtained by the Plant, and after the streams of mixed waste and waste collected selectively were separated.

Table 3. Balance of the amount of municipal mixed waste treated mechanically, and waste generated as a result of this process at the Waste Management Plant in Poświętne from May to December 2016 - a personal study (using [13]).

\begin{tabular}{|c|c|c|c|c|}
\hline \multicolumn{2}{|c|}{ Mechanical treatment - input waste } & \multicolumn{2}{|c|}{ Waste after a mechanical processing } & \multirow{2}{*}{$\begin{array}{l}\text { Percentage of } \\
\text { generated waste } \\
\text { to the sum of } \\
\text { input waste [\%] }\end{array}$} \\
\hline Type of waste & $\begin{array}{c}\text { Waste } \\
\text { mass }[\mathrm{Mg}]\end{array}$ & $\begin{array}{l}\text { Type of waste } \\
\text { (waste code) }\end{array}$ & $\begin{array}{c}\text { Waste } \\
\text { mass }[\mathrm{Mg}]\end{array}$ & \\
\hline \multirow{8}{*}{$\begin{array}{l}\text { Unsorted municipal } \\
\text { waste (mixed waste) } \\
\text { (20 } 0301)\end{array}$} & \multirow{8}{*}{39546.7} & $\begin{array}{l}\text { Packaging (paper and } \\
\text { cardboard, plastic, metal, } \\
\text { multi-material, glass) } \\
\text { (ex } 150101 \text {, ex } 150102, \\
\text { ex } 150104 \text {, ex } 150105, \\
\text { ex } 150107 \text { ) }\end{array}$ & 1563.2 & 3.94 \\
\hline & & $\begin{array}{c}\text { Batteries and } \\
\text { accumulators } \\
(160601 * \text { and } 160605)\end{array}$ & 0.3 & below 0.01 \\
\hline & & $\begin{array}{c}\text { Paper and cardboard } \\
(191201)\end{array}$ & 41.4 & 0.10 \\
\hline & & $\begin{array}{l}\text { Ferrous metals } \\
\quad(191202)\end{array}$ & 85.8 & 0.22 \\
\hline & & $\begin{array}{l}\text { Other waste from } \\
\text { mechanical waste } \\
\text { processing (high energy } \\
\text { fraction) } \\
(191212)\end{array}$ & 5299.5 & 13.40 \\
\hline & & $\begin{array}{l}\text { Other waste from } \\
\text { mechanical waste } \\
\text { processing (ballast) } \\
(191212)\end{array}$ & 8601.8 & 21.75 \\
\hline & & $\begin{array}{c}\text { Other waste from } \\
\text { mechanical waste } \\
\text { processing (large-size } \\
\text { waste) } \\
\text { (19 12 12) } \\
\end{array}$ & 1716.6 & 4.34 \\
\hline & & $\begin{array}{l}\text { Other waste from } \\
\text { mechanical waste } \\
\text { processing }(0-80 \mathrm{~mm} \\
\text { fraction) } \\
(191212) \\
\end{array}$ & 5198.0 & 48.04 \\
\hline TOTAL & 39546.7 & TOTAL & 36302.1 & 91.80 \\
\hline
\end{tabular}

* the loss results from the significant water content in municipal waste (outflow of leachate after opening the bags)

\section{Analysis of the results}

Analysing the data from Tables 1 and 3, it should be noted that as a result of the mechanical treatment of combined waste streams: mixed municipal waste and waste from separate collection in the first half of 2016 (before obtaining the integrated permit), the undersieve fraction (i.e. of $0 \div 80 \mathrm{~mm}$ granulation) was at the level of about $57 \%$ of the input. This 
fraction requires further processing through biological methods (stabilization). At the time, the mixed waste and the waste collected selectively were treated together, which is inconsistent with the provisions of EU law.

In the second quarter of 2016 (after obtaining the integrated permit), and as a result of mechanical treatment, the subscreen fraction was at the level of $48 \%$ of the amount of mixed waste. At the time, the mixed waste and the waste collected selectively were treated separately, which is the right solution from the point of view of waste management legislation.

The sorted out secondary raw materials and the high calorific fraction in the first half of 2016 accounted for almost $23 \%$. A similar amount was obtained in the second quarter, as a result of mechanical processing of the mixed municipal waste - approximately $22 \%$. Compared to that - the sum of these separated streams coming from the sorting of selectively collected waste accounted for almost $93 \%$.

Refuse derived fuel - obtained as a result of the mechanical treatement of solely selectively collected waste constitutes about $21 \%$ of the input (Table 2). However, segregation of the mixed municipal waste stream resulted in the generation of refuse derived fuel in an amount from $10 \%$ to about $13 \%$ (Tables 1 and 3 ).

The analysis given in Tables 1-3 shows that the so-called ballast (19 12 12) - waste requiring final disposal in a landfill- obtained as a result of the mechanical treatement of solely selectively collected waste constitutes only about $7 \%$ of the input (Table 2). However, segregation of the mixed municipal waste stream resulted in the generation of this waste in an amount from $17 \%$ to almost $22 \%$ (Tables 1 and 3 ).

Data regarding the operational results of the analyzed waste treatment plant are presented in Figures 1-3, which show the effectiveness of modern solutions for municipal systems in the field of waste management using the example of the Waste Management Plant in Poświętne.

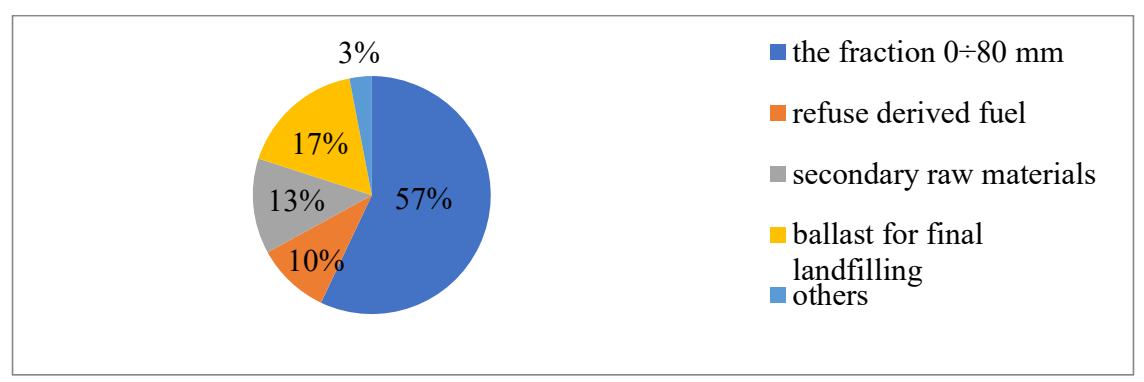

Fig. 1. Fractions sorted out from mixed municipal waste (operation before obtaining the integrated permit - combined processing for mixed municipal waste and separately collected waste).

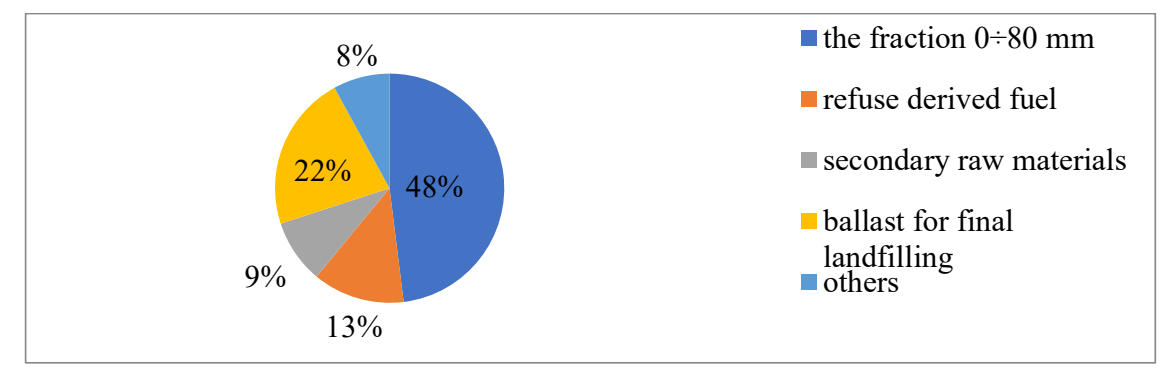

Fig. 2. Fractions sorted from mixed municipal waste (operation after obtaining the integrated permit separate processing for mixed municipal waste and separately collected waste). 


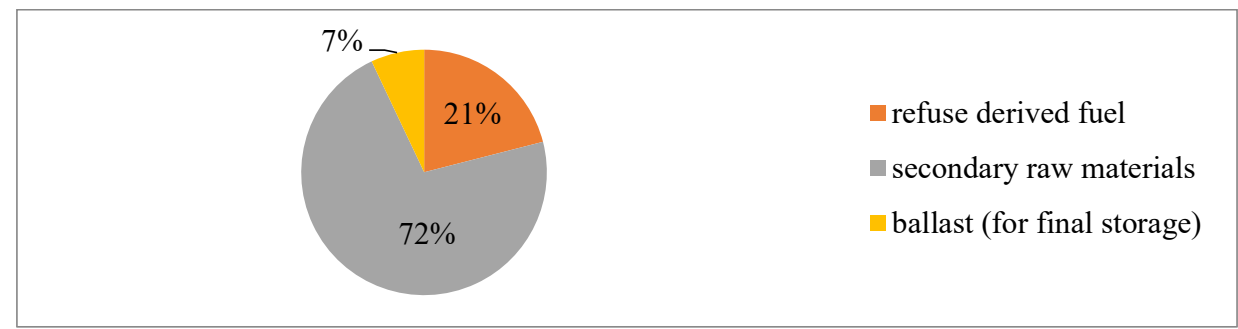

Fig. 3. Fractions sorted from selectively collected municipal waste (operation after obtaining the integrated permit - separate processing for mixed municipal waste and separately collected waste).

\section{Summary and conclusions}

The work analysed the data on mechanical processing in a plant for the mechanicalbiological treatment of municipal waste. The mechanical part of the installation is equipped with electromagnetic separators, sorting cabins, sieves, bag breakers and one of the most modern devices used in municipal waste management - optical-electronic separators. Results were obtained to compare the efficiency of separation of secondary raw materials and energy fractions (refuse derived fuel) for further use, as well as the amount of undersieve fraction requiring biological stabilization and ballast waste, which is directed to landfilling. The analysis allows concluding that the mechanical processing of separately collected waste is characterized by a much greater efficiency than the processing of mixed waste - much more diverse, contaminated, with a higher level of humidity. It is expressed by a much greater amount of secondary raw materials and energy fraction obtained from separately collected waste, which is subjected to mechanical pre-processing.

At the same time, the mechanical treatment of mixed municipal waste generates a larger number of fractions that require final disposal at the landfill (so-called ballast). It should be emphasized that in 2030 the amount of municipal waste directed to landfills will not be allowed to exceed $10 \%$ [14]. These requirements were met in the analysed Plant during the mechanical pretreatment of waste from separate collection, but they were exceeded in the mechanical treatment of mixed municipal waste. However, one should be aware of the fact that not only the above-mentioned waste (so-called ballast) requires final disposal through storage. The amount of undersieve fraction from the mechanical processing of mixed municipal waste is at a high level - in the range from $48 \%$ to $57 \%$. This waste is then sent for biological processing, and a large part of it will also require landfilling after stabilization.

A higher efficiency of mechanical processing of selectively collected waste and large amounts of undersieve fraction from the mechanical treatment of mixed municipal waste motivates the implementation of separate collection of municipal waste. However, it is also worth noting that in this case it is significant whether this collection is carried out properly, eliminating irregularities related to, among others, collection of closed packaging, filled with liquids or waste in the form of used diapers, medicines, etc.

The presented Waste Management Plant in Poświętne is an example of the use of modern equipment and utilities of municipal systems. Such installations provide the opportunity for the sustainable development of city infrastructure, the chance to minimize the negative impact of urban structures on the environment and to implement the assumptions related to the circular economy. The use of modern technologies and compliance with the procedures required by law (required administrative decisions) gives the opportunity to properly manage the municipal structure in the field of waste management and the chance of waste management in accordance within the waste hierarchy. 
The examined installation is one of many operating technological solutions that are part of the infrastructure of Polish cities. Observing the work of other mechanical and biological treatment plants, similarities in the technological processes and equipment can be noticed. The operation is controlled by a computer. This enables constant monitoring of the process, rapid response in the case of failure, and the most effective separation of useful fractions, including fuels from waste.

\section{References}

1. K. Bohniewicz, D. Pańczuk, Kompleksowe rozwiązania do przesiewania, separacji i sortowania odpadów komunalnych, materials from VII Mechanical and biological waste processing conference (2015)

2. F. Fei, Z. Wen, S. Huang, Mechanical biological treatment of municipal waste : Energy efficiency, environmental impact and economic feasibility analysis, JCP, vol. 178, 731739 (2018)

3. E. Nevarova-Dziopak, Normowanie jakości środowiska jako narzędzie realizacji rozwoju zrównoważonego - Standardization of environment as a tool of implementation of sustainable development, W: INFRAEKO 2009: Infrastruktura komunalna a rozwój zrównoważony terenów zurbanizowanych, III ogólnopolska konferencja naukowo-techniczna, Rzeszów-Niepołomice, pod red. J. Dziopak, D. Słyś, A. Stec, Rzeszów, Oficyna Wydawnicza Politechniki Rzeszowskiej, S. 175-184 (2009)

4. M. Wiśniewska, K. Lelicińska-Serafin, Rola i efektywność instalacji MBP w Polsce na wybranych przykladach (to be published in Zeszyty Naukowe Uniwersytetu Zielonogórskiego, Seria : Inżynieria Środowiska)

5. B. Ruj, V. Pandey, P. Jash, V. K. Srivastava, Sorting of plastic waste for effective recycling, Int. JASER, vol. 4, Issue 4 (2015)

https://www.researchgate.net/publication/305503715_Sorting_of plastic_waste for_eff ective recycling

6. C. Cimpan et al., Journal of Environmental Management 156, 181-199 (2015)

7. Act of 14 December 2012 on Waste, consolidated text Journal of Laws of 2018, item 992 (2018)

8. Directive 2010/75/EU of the European Parliament and of the Council of 24 November 2010 on industrial emissions (integrated pollution prevention and control) (2010)

9. M. Wiśniewska, K. Lelicińska-Serafin, Biologiczne przetwarzanie odpadów komunalnych w PGK Płońsk na przykładzie odpadów odebranych z obszaru gminy Bodzanów, W: Inżynieria Środowiska - Młodym Okiem, pod red. I. Skoczko, K. Gładyczewskiej-Fiedorczuk, K. Weremijewicz, A. Witkowskiej, Białystok, Oficyna Wydawnicza Politechniki Białostockiej, vol. 35, S. 90-101 (2017)

10. Marshall of Mazowieckie Voivodeship, Decision No. 58/16/PZ.Z for the Waste Management Plant in Poświętne (2016)

11. A. Jędrczak, Biologiczne przetwarzanie odpadów komunalnych, Wydawnictwo Naukowe PWN (2008)

12. W. Kępys, Opto-pneumatic Separators in Waste Management, JPMES, January-June (2016) https://yadda.icm.edu.pl/baztech/element/bwmeta1.element.baztech-7274fef1b310-457a-8b1b-f5f9e2053876/c/IM 1-2016-a9.pdf

13. Balance of waste from the Municipal Waste Treatment Plant in Poświętne - information obtained from the plant (not published) (2016)

14. Resolution No. 88 of the Council of Ministers of 1 July 2016 on the National Waste Management Plan 2022, (Monitor Polski No. 88, item 784) (2016) 